\title{
BAJECZNO-MITYCZNA GENEZA PORTUGALII W ZWIERCIADLE PIERWSZEJ I DRUGIEJ CZĘŚCI MONARCHIA LUSITANA BERNARDA DE BRITO
}

\author{
Anna Działak-Szubińska ${ }^{1}$ \\ https://doi.org/10.18778/8220-421-6.12
}

\begin{abstract}
Tales on the origins of Portugal are based on mythological, biblical and historical motifs. They gain a large degree of resonance in the context of the Iberian Union (1580-1640). From the rich body of works developed in that period there is one that merits closer attention: Monarchia Lusitana - the history of Portugal first taken up by the Cistercians of the Santa Maria de Alcobaça monastery. Following the analysis of the work's structure and content and by making reference to the research of, among others, Jacek Banaszkiewicz on "de origines", the present chapter goes over the mythical roots of Portugal as reflected in the first and the second part of the Monarchia Lusitana (1597 and 1609) chronicle project started by Bernardo de Brito (1569-1617).
\end{abstract}

Keywords: Bernardo de Brito, Monarchia Lusitana, origins of Portugal, legendary history, the Iberian Union.

Słowa kluczowe: Bernardo de Brito, Monarchia Lusitana, geneza Portugalii, dzieje bajeczne, unia iberyjska.

1 Instytut Studiów Iberyjskich i Iberoamerykańskich Uniwersytetu Warszawskiego, ul. Oboźna 8, 00-332 Warszawa. 


\section{Założenia wstępne}

Jak pisze Jacek Banaszkiewicz, „[m]ieć swój początek, to znaczy być podmiotem dziejów" (Banaszkiewicz, 1997: 44). Stąd też narracje o „dziejach początkowych” (por. Banaszkiewicz, 1998) to niezwykle popularny temat, który w kręgu europejskim powraca w różnych epokach. To z tego kontekstu wyrasta także Monarchia Lusitana - wielotomowa historia Portugalii zapoczątkowana przez Bernarda de Brito (1569-1617), cystersa z klasztoru Santa Maria de Alcobaça. Jest on autorem dwóch pierwszych tomów dzieła, które ukazały się drukiem odpowiednio w latach 1597 i 1609. Jego pracę kontynuowali do 1729 roku kolejni mnisi.

Odwołując się między innymi do badań Jacka Banaszkiewicza nad szczególną rolą i nośnością opowieści „de origines” (por. Banaszkiewicz, 1998), przedstawię korzenie Portugalii w zwierciadle pierwszej i drugiej części Monarchia Lusitana autorstwa Bernardo de Brito. Jak pokażę, cysters nobilituje swoją ojczyznę poprzez jej genezę, której istotnym elementem są między innymi odniesienia do kultury antycznej: erudycyjne przykłady, wątki z dziejów, mitologiczne konteksty, literackie odwołania, kunsztowne cytaty... Nie chciałabym jednak skupiać się na wymienianiu „bajecznych” przykładów odwołujących się do czasów starożytnych, lecz spojrzeć na pracę Bernarda de Brito holistycznie i zastanowić się, jakim celom służy utkana przez niego opowieść „de origines”. Przedstawię również strukturę i treść pracy ze szczególnym uwzględnieniem elementów odnoszących się właśnie do genezy Portugalii.

\section{2.}

\section{Rama wydawnicza pracy}

Bernardo de Brito był tak aktywny literacko, że w 1614 roku, po śmierci naczelnego kronikarza królestwa (cronista-mor) objął tę zaszczytną funkcję, zaś w roku 1615 zlecono mu uporządkowanie ksiąg w Torre do Tombo, królewskim archiwum (da Silva 
Rego, w: de Brito, 1973: XV). Pierwszy tom Monarchia Lusitana docenił zaś sam Filip II (I) Habsburg2 ${ }^{2}$, zalecając listownie kontynuację prac nad drugą częścią dzieła (de Brito, 1975: bez numeracji kart, por. da Silva Rego, w: de Brito, 1975: XII; Gloël, 2017: 33-35).

Lekturę Monarchia Lusitana warto zacząć właśnie od ramy wydawniczej, a więc, w słowach Renardy Ocieczek, „elementów piśmienniczych dodanych do tekstu głównego dzieła, wprowadzających lub zamykających tenże tekst" (Ocieczek, 1990: 7). Przyjrzymy się zatem elementom otwierającym pierwszą część dzieła, a przede wszystkim: karcie tytułowej, aprobacjom cenzorskim i przedmowom ${ }^{3}$.

Zacznijmy od kart tytułowych. Pełny tytuł pierwszej części pracy (de Brito, 1973) to: Monarchia Lusitana composta por Frey Bernardo de Brito, chronista geral \& religioso da ordem de S. Bernardo, professo no Real mosteiro de Alcobaça. Parte Primeira que contem as historias de Portugal desde a criação do mundo te o nacimento de nosso sñor Iesu Christo. [Monarchia Luzytańska napisana przez Brata Bernarda de Brito, naczelnego kronikarza i mnicha zakonu św. Bernarda w królewskim klasztorze Alcobaça. Część pierwsza, która zawiera historię Portugalii od stworzenia świata do narodzin naszego pana Jezusa Chrystusa] zostaje uzupełniony o informacje dotyczące przypisania i zleceniodawcy dzieła - Dirigida ao Catholico Rei Dó Philippe II do nome RE de Espanha Emperador do novo mundo. Impressa

$2 \mathrm{~W}$ interesującym nas okresie Portugalia była połączona unią personalną z Hiszpanią. Stąd stosuję zapis z podwójną sygnaturą: Filip II Habsburg - Filip II (I), Filip III Habsburg - Filip III (II), Filip IV Habsburg - Filip IV (III), gdzie druga sygnatura odnosi się do Portugalii.

3 W przypadku obu tomów korzystam $z$ faksymiliów pierwszych wydań prac (de Brito, 1973 oraz de Brito, 1975). Rama wydawnicza późniejszych wydań jest odmienna, przykładowo w wydaniach pierwszego i drugiego tomu z 1690 roku znajdziemy między innymi dedykację dla króla Piotra II z dynastii Bragança, zaś przypisanie prac do Habsburgów zostanie usunięte (por. de Brito, 1690a; de Brito, 1690b). 
no Insigne mosteiro de Alcobaça por mandado do R. mo Padre Geral Frey Francisco de S Clara com licenca \& privilegio Real Anno de 1597 [Skierowana do Katolickiego króla D. Filipa drugiego tego imienia Króla Hiszpanii, Imperatora nowego świata. Wydrukowana w przesławnym klasztorze Alcobaça na polecenie Wielebnego Ojca Przełożonego Brata Francisca de S. Clara z pozwoleniem i przywilejem królewskim w roku 1597] ${ }^{4}$.

W przypadku drugiej części (de Brito, 1975) komplet informacji zawartych na karcie tytułowej jest następujący: Segunda Parte da Monarchia Lusytana em que se continuão as historias de Portugal desde o nascimento do nosso Salvador Iesu Christo, ate ser dado em dote ao Conde dom Henrique. Dirigida ao Catholico Rey dom Phelippe, segundo do nome em Portugal, \& terceiro em Castella, senhor d'Espanha, Emperador do novo mundo. E composta por seu mandado, pello Doutor Frey Bernardo de Britto Chronista gèral, \& monge da Ordem de São Bernardo. Impressa em Lisboa no Mosteiro de São Bernardo, com licença e Privilegio Real. Por Pedro Crasbeeck. Anno Dñi 1609. [Druga część Monarchii Luzytańskiej, w której kontynuowane sa dzieje Portugalii od narodzin naszego Zbawiciela Jezusa Chrystusa po przekazanie jej jako posagu hrabiemu Henrykowi. Skierowana do Katolickiego Króla Dom Filipa, drugiego tego imienia w Portugalii i trzeciego w Kastylii, pana Hiszpanii, Imperatora nowego świata. Napisana z jego rozkazu przez Doktora Ojca Bernardo de Brito, naczelnego kronikarza i mnicha Zakonu św. Bernarda. Wydrukowana w Lizbonie w Klasztorze Św. Bernarda z pozwoleniem i przywilejem królewskim przez Pedra Crasbeecka w Roku Pańskim 1609].

Dowiadujemy się zatem, jakie cezury przyjął dla swej pracy kronikarz: od początku świata do narodzin Chrystusa w ramach pierwszej części i od narodzin Chrystusa do przekazania Portugalii hrabiemu Henrykowi w ramach drugiej części. Co więcej, zgodnie z zawartymi informacjami, obie prace są dedykowane Habsburgom - odpowiednio Filipowi II (I) i Filipowi III (II), zaś pierwsza część powstaje z inspiracji zakonnego przełożonego

4 Wszystkie tłumaczenia, o ile nie wskazano inaczej, sporządziła autorka rozdziału. 
cystersa, a druga na polecenie samego króla. Co ważne, oba omawiane tu tomy ukazały się z królewskim przywilejem. To także tutaj ujawnia się podejście Bernarda de Brito do materii historycznej - pisze wszak o dziejach „Monarchii Luzytańskiej”, a więc Portugalii, której początki, zgodnie ze wskazanymi cezurami, są zlokalizowane niemalże u zarania świata.

Po karcie tytułowej w obu częściach następują wszystkie niezbędne aprobacje cenzorskie, które realizują trzypoziomowy model cenzury prewencyjnej (cenzura papieska - pozwolenie inkwizycyjne, episkopalna - pozwolenie ordynariusza i królewska - pozwolenie z ramienia królewskiego) (porównaj de Almeida Rodrigues, 1980: 14-15). Dodatkowo w przypadku tej pracy znajdziemy aprobację od bezpośrednich przełożonych mnicha.

Aprobacje cenzorskie zazwyczaj są do siebie podobne - książki dopuszczone do druku i dystrybucji są, w słowach cenzorów, godne wydrukowania i ciekawe oraz nie zawierają nic niezgodnego $\mathrm{z}$ wiarą i $\mathrm{z}$ dobrymi obyczajami. Formuły te znajdziemy nawet $\mathrm{w}$ tych pracach, w których cenzorzy zdają się wyrażać autentyczne uznanie dla ocenianego dzieła (por. Działak-Szubińska, 2015: 5-6). Dokumenty odtwarzają też wspomniany trzypoziomowy model - cenzorzy reprezentujący wszystkie „instancje” nawiązują do aprobacji poprzedników. Również w przypadku Monarchia Lusitana zgoda na druk zostaje wydana w oparciu o własny osąd i opinie poprzedników. Cenzorzy zwracają uwagę na przydatność i stosowność dzieła, autorowi zaś zalecają kontynuowanie prac pisarskich. Zapisy są podobne w przypadku obu części, nie wydają się też specjalnie spersonalizowane (de Brito, 1973: 1r i kolejne; de Brito, 1975: bez numeracji kart), choć w drugim tomie jeden z cenzorów pisze, że dzieło jest „nie tylko godne wydania pozwolenia drukarskiego i wydrukowania, ale też zasługuje na pochwałę i wiele słów podziękowania" (de Brito, 1973: bez numeracji kart). Ustandaryzowane formuły zawierają więc, być może, nieco autentycznego uznania dla pracy cystersa.

Za pozwoleniami drukarskimi następują wyrafinowane i erudycyjne dedykacje skierowane w pierwszej kolejności do panujących monarchów: w przypadku pierwszej części jest to Filip II (de Brito, 1973: Iv-2r), zaś w drugiej części Filip III (de Brito, 
1975: bez numeracji kart). Pierwszy tom zawiera także podziękowanie dla przełożonego cystersa, Francisca de Santa Clara - za nauki klasztorne i uwagę poświęconą kronice. Interesująca jest tu też perspektywa dziejowa, jaką przyjmuje autor. Otóż kronika jest postrzegana jako spłata długu wobec pierwszego króla Portugalii, Alfonsa Henriquesa, fundatora klasztoru i według słów Brito „pierwszego autora Monarchii Luzytańskiej” (de Brito, 1973: 2v).

Następnie w obu tomach znajdziemy dedykację dla czytelników (de Brito, 1973: 3r-5v, de Brito, 1975: bez numeracji kart). To tutaj Bernardo de Brito przedstawia swoją wizję historiozoficzną. I tak w pierwszym tomie twierdzi, że kroniki stanowią źródło wzorów dla władców i innych ludzi, żeby wiedzieli, jak postępować w życiu. Podkreśla również rolę historii w poznaniu (de Brito, 1973: 3r). W tym kontekście odnosi się także do kwestii językowych: wskazuje, że celowo nie wybrał łaciny, lecz język portugalski, by pokazać Portugalczykom ich dzieje własne (de Brito, 1973: 4r). Celem, jak zaznacza, nie jest więc jego własna sława, lecz sława ziemi ojczystej (de Brito, 1973: 4r). Odnotowuje też, że brak jest wystarczającej liczby opracowań dotyczących dziejów Portugalii (de Brito, 1973: 3r-3v).

Z kolei w drugiej części (de Brito, 1975: bez numeracji kart) Bernardo de Brito powtarza, że praca ma sprawić, że wybitne czyny Portugalczyków ujrzą światło dzienne. Pisanie jest też ponownie przedstawione jako służba ojczyźnie. Mnich zamieszcza również niezwykle przychylne listy otrzymane od króla, które pozwalają przedstawić dzieło jako następstwo polecenia wydanego przez władcę. Nawiązuje do tego, jak wspomniałam, również informacja na karcie tytułowej pracy.

W pierwszej części, tuż po prologach, umieszczone są również listy potwierdzające użycie dawnych źródeł nieznanych szerszemu gronu czytelniczemu (de Brito, 1973: 5v-6v) oraz stosowne deklaracje autora związane z użyciem dokumentów, które mogą potencjalnie zawierać niestosowne treści (de Brito, 1973: 6v, 8v), a także teksty poetyckie dedykowane autorowi (de Brito, 1973: 5v, bez numeracji kart). Podobne informacje znajdują się w drugim tomie (de Brito, 1975: bez numeracji kart) 
w części poprzedzającej prolog skierowany do czytelników i zatytułowanej „Deklaracja autora”.

W przypadku pierwszej części po prologach znajduje się również spis treści (de Brito, 1973: bez numeracji kart) oraz indeks cytowanych autorów (de Brito, 1973: 7r-8v). Dodajmy też, że w przypadku drugiego tomu na samym końcu pracy znajduje się epigramat autorstwa Manuela Severima de Farii, znanego erudyty, indeks osób i rzeczy oraz errata (de Brito, 1975: bez numeracji kart).

Reasumując, rama wydawnicza zawiera pewną pulę informacji dotyczących celów pracy, przyjętych w niej cezur oraz jej recepcji. Choć, jak zobaczymy, treści wynikają ze swoistych konwencji pisarskich, dają nam jednak wgląd w kolejne procesy: pisarski, drukarski i czytelniczy 5 .

\section{3.}

\section{Metodologia pracy Bernarda de Brito - między krytycznym podejściem a ,fatszerstwem”}

Przyjrzyjmy się teraz metodologii pracy Bernarda de Brito. Na uwagę zasługuje tu przede wszystkim bogaty zasób źródeł, do których odwołuje się dziejopis (por. da Silva Rego, w: de Brito, 1973: XVI-XIX, XXIV). Są to głównie źródła pisane, zaś informacje na ich temat znajdziemy między innymi w obszernym i różnorodnym indeksie cytowanych autorów, wśród których znajdziemy historyków, ojców Kościoła czy poetów (de Brito, 1973: $7 \mathrm{r}-8 \mathrm{v}$ ). Zgodnie z wykazem autor sięgał zarówno po różnorodne prace klasyczne (Tytus Liwiusz, Tukidydes, Marek Tulliusz Cyceron), średniowieczne (święty Tomasz z Akwinu, Lucas de Tuy), jak i nowożytne (Luís Vaz de Camões, Damião de Góis). We wzmiankowanym indeksie znajdziemy również dokumenty

5 O konwencjach, częściach składowych i stałych elementach ramy literacko-wydawniczej zobacz na przykład Ocieczek, 1990: 8-9 i kolejne. 
aktowe, na przykład pisma z Soboru Trydenckiego, a także święte księgi innych religii - Koran i Talmud. Kronikarz, jak sam deklaruje, korzystał między innymi z prac rękopiśmiennych, zaś dokumentów poszukiwał nie tylko w rodzimym klasztorze, ale w całej Hiszpanii. Co ważne, gdzie było to możliwe, starał się sięgać do oryginałów prac (de Brito, 1973: 5r). Ta bogata baza źródłowa znajduje również odzwierciedlenie w siatce odnośników umieszczonych na marginesach księgi - autor stara się poświadczyć przytaczane fakty poprzez konkretne odwołania. To treść kroniki ujawnia również, że Bernardo de Brito nie ograniczał się do ksiąg i akt, ale korzystał także ze źródeł epigraficznych (zob. da Silva Rego, w: Brito, 1973: XXIV; da Silva Rego, w: Brito, 1975: XIII). Nadmieńmy, że w związku z użyciem tak różnorodnych prac autor składa dwa, wchodzące w skład ramy literacko-wydawniczej oświadczenia, w których potwierdza, że korzystał z dokumentów w dobrej wierze i unikał herezji (de Brito, 1973: 6v, 8v).

W świetle powyższych ustaleń praca wydaje się niezwykle rzetelna. Przy czym należy zaznaczyć, że repertorium autorów cytowanych przez Bernarda de Brito należy do swoistego nowożytnego standardu 6 . Dlatego nie możemy mieć pewności, że Bernardo de Brito faktycznie znał całościowo wszystkie przytaczane dzieła $^{7}$.

W tym kontekście trzeba też pamiętać, że dziejopis był oskarżany o rozmaite „fałszerstwa” (da Silva Rego, w: de Brito, 1973: XXV i kolejne, por. też Łukaszyk, 2003: 92-93). I tak jedno z jego głównych źródeł informacji, Laymundo Ortega (de Brito, 1973: 4v, por. da Silva Rego, w: de Brito, 1973: XVII), jest autorem, którego autentyczność była negowana - krótko mówiąc, zarzucono Bernardo de Brito, że powoływał się na nieistniejącą pracę wymyślonego dziejopisa (zob. da Silva Rego, w: de Brito, 1973: XXVII).

6 Szerzej na temat źródeł porównaj na przykład źródła wiedzy nowożytnego portugalskiego humanisty Fernão de Oliveiry szczegółowo odtworzone przez José Eduardo Franco (Franco, 2000: 138-185).

7 O kwestiach związanych między innymi z cytowaniem i lekturą bardzo ciekawie pisze Wiesław Pawlak (por. Pawlak, 2012). 
Nadmieńmy, że w Monarchia Lusitana znajdziemy wymyślone akty z rzekomych XII-wiecznych kortezów w Lamego czy oficjalne potwierdzenie ukazania się Chrystusa Alfonsowi Henriquesowi podczas bitwy pod Ourique w 1139 roku (Brandão, 1632: 119r-29 v; 141v-145r i kolejne, porównaj też da Silva Rego, w: de Brito, 1973: XXVIII-XXX8; Vásquez Cuesta, 1986: 108-109; Saraiva, 2010: 227-228; Łukaszyk, 2003: 92-93). Natomiast w Chronica de Cister (1602), której autorem także jest de Brito, pojawiają się dokumenty dosłownie stworzone na jej potrzeby. Należy do nich na przykład rzekomy list, który matka pierwszego króla Portugalii, Teresa, miała mu wysłać wraz z dyspozycjami na okoliczność swojej śmierci, w tym prośbą o specjalne przywileje dla cystersów, a więc zakonu, z którym związany był kronikarz (de Brito, 1602: $67 \mathrm{r}-69 \mathrm{v}$ ). W następstwie kontrowersji związanych z Monarchia Lusitana powstał cały szereg prac dyskredytujących bądź broniących jej pierwszego autora (zob. da Silva Rego, w: de Brito, 1973: XXV-XXIX, spośród prac dyskutujących wiarygodność Monarchia Lusitana por. na przykład da Silva, 1620).

W kontekście „fałszerstw” José Hermano Saraiva napisał, że zgodnie z metodologią cystersa to „historia tworzy dokument, a nie dokument historię" (Saraiva, 2000: 228), zaś Lopes i Saraiva zwrócili uwagę na równoważne traktowanie wszystkich typów źródeł - także tych nie wytrzymujących próby krytyki źródłowej (Lopes i Saraiva, 1996: 424). Odnośnie do metodologii Bernardo de Brito możemy więc zauważyć, że paradoksalnie łączy ona oczytanie, różnorodny dobór źródeł i uważną analizę z - jak się wydaje - nierzetelnością, która, jak zaraz pokażę, jest jednak podporządkowana konkretnym celom.

8 Przy czym António da Silva Rego sugeruje raczej, że de Brito został oszukany przez fałszerzy, a nie sam tworzył dokumenty na poparcie swych tez (patrz da Silva Rego, w: Brito, 1973: XXIX-XXX). Wskazuje też, że formułowane zarzuty mogły być uwarunkowane osobistymi antypatiami (da Silva Rego, w: de Brito, 1973: XVI, XXV-XXVI). 


\section{4.}

\section{Układ i tematyka Monarchia Lusitana Bernarda de Brito}

Jak już wspomniałam, autor zaznacza w prologach do obu części dzieła, że w Portugalii nie ma dostatecznego bogactwa prac historycznych. Choć podobne sformułowania znajdziemy i w innych pracach tego okresu, i wpisują się one oczywiście w topikę wstępu (por. Curtius, 1997: 92-96), w Portugalii faktycznie nie powstała wcześniej aż tak obszerna praca poświęcona jej dziejom. Monarchia Lusitana miała bowiem stanowić kompletną historię Portugalii, przedstawiającą ponadto panoramę jej dziejów na tle dziejów świata. Według początkowych planów praca miała obejmować zresztą następujące pozycje: Monarchia Gentilica, Monarchia Gotica/Sarracenica, Monarchia Catholica, a więc przybliżać dzieje Portugalii od genezy ludów zamieszkujących tereny Portugalii po czasy sobie współczesne (da Silva Rego, w: de Brito, 1973: XIII).

I choć ostatecznie praca ma dużo więcej tomów, które są zorganizowane podług nieco innej logiki, i nie sięga do czasów Filipów, układ wydarzeń w Monarchia Lusitana jest chronologiczny. W przypadku interesujących nas tomów obejmuje podstawową sekwencję poprzedzającą powstanie królestwa Portugalii, a więc czasy poprzedzające przybycie Rzymian na Półwysep Iberyjski, czasy rzymskie, najazdy barbarzyńców, panowanie muzułmańskie i rekonkwistę. Zwieńczenie pracy stanowi wyodrębnienie hrabstwa Portugalii z Królestwa Kastylii i Leónu za panowania Alfonsa VI. Nadmieńmy przy tym, że czasy poprzedzające przybycie Rzymian na Półwysep Iberyjski obejmują sekwencję dziejową rozpoczętą przez zaludnianie ziemi po biblijnym potopie. Bernardo de Brito poświęca więc uwagę dziejom Portugalii od momentu, gdy ziemie Półwyspu Iberyjskiego zostały zaludnione przez potomków Noego aż do powstania lenna, z którego narodzi się Portugalia. Początek organizacji państwowej zostaje zatem wpleciony w czasy poprzedzające rzeczywiste powstanie Portugalii. Co więcej, wydarzenia poświadczone źródłowo i erudycyjne rozważania przeplatają się z opowieściami 
zbudowanymi na kontekstach mitycznych, takimi jak pobyt Odyseusza na Półwyspie Iberyjskim i rządy Herkulesa oraz biblijnymi, na przykład zaludnienie Półwyspu Iberyjskiego przez potomków Tubala. Równocześnie wydarzenia mające miejsce na Półwyspie Iberyjskim zostają wkomponowane w tło dziejów powszechnych - de Brito zawsze pokazuje wszystkie opowieści w paralelnym rzucie iberyjskim i powszechnym. Układ pracy jest regularny i symetryczny - podporządkowany odgórnie narzuconej strukturze kompozycyjnej (por. da Silva Rego, w: de Brito, 1973: XIX-XX, da Silva Rego, w: de Brito, 1975: XI-XII).

Oczywiście historia Portugalii wpisana w szerszy kontekst była przedmiotem rozważań innych dziejopisów - tego typu narracje były istotnym elementem legitymizacyjno-prestiżowym tak w średniowieczu, jak i w epoce nowożytnej. Co więcej, wydarzenia prezentowane przez de Brito wpisują się niejako w iberyjski kanon dziejów bajecznych. $Z$ materiału osadzonego w portugalskim kontekście wymieńmy tu zatem chociażby znane nowożytnym erudytom XIV-wieczne Livros de Linhagens hrabiego Piotra (opracowanie Herculano, 1860), Crónica Geral de Espanha de 1344 - portugalską wersję Crónica General de España (wydanie krytyczne Lindley Cintra, 1951) czy dwie prace Fernão de Oliveiry (de Oliveira, w: Franco, 2000: 351-522). Zarówno pracom wcześniejszym, jak i tym, które powstaną już po wydaniu pierwszych tomów Monarchia Lusitana (na przykład de Sousa de Macedo, 1631, por. na przykład Działak-Szubińska, 2015: 1-18) daleko jednak do kompleksowości prac kronikarskich cystersów. Nadmieńmy, że - jak wskazuje Matthias Gloël - de Brito był także inspiracją dla innych pisarzy zajmujących się „wspaniałościami” Portugalii (Gloël, 2017: 42).

Przykładowo wątek przybycia Ulissesa, rzekomego eponima Lizbony, na Półwysep Iberyjski był niezwykle nośnym tematem poruszanym między innymi przez poetów (na przykład Camões 1995: VIII, 5), zaś postpotopowa rzeczywistość iberyjska była przedmiotem wielu lektur historiograficznych na półwyspie i nie tylko. I tak o Tubalu pisał chociażby św. Izydor z Sewilli czy Jan Długosz (por. Długosz, 2009: 90-1, przypis 7 ze strony 90), zaś w kontekście ściśle portugalskim o pochodzeniu mieszkańców 
Półwyspu Iberyjskiego od tego wnuka Noego opowiadała na przykład Crónica Geral de Espanha de 1344 (opracowanie Lindley Cintra, 1951: 13 i kolejne), w kolejnych wiekach nawiązywał do niej także wspomniany już Fernão de Oliveira (Oliveira, w: Franco 2000: 351-358, por. też Gloël, 2017: 36 przypis 12). Podobnie znany był wątek rządów Herkulesa (opracowanie Lindley Cintra, 1951: 16 i kolejne). Z antycznych wątków historycznych, co oczywiste, znajdziemy u Bernarda de Brito opowieść o Wiriatusie i jego walkach z Rzymem - przedmiot rozlicznych opowieści kronikarskich i epickich, obecny chociażby w istotnej z perspektywy omawianego okresu pracy Luísa Vaza de Camõesa, Luzytanie (Camões, 1995: VIII, 6-8). Z kart Monarchia Lusitana przebija szacunek dla starożytności (o szacunku do starożytności por. Pomian, 2010: 61 i kolejne) - tak greckiej, jak i rzymskiej - choć duży nacisk jest też kładziony na wątki biblijne, rolę walki rdzennych plemion z Rzymianami czy motyw rzekomej kartagińskiej spuścizny Portugalczyków (por. Gloël, 2017: 36-37)9.

Przekazana przez Bernarda de Brito opowieść o dziejach Portugalii jest więc prawdziwie eklektyczna: $w$ wizji cystersa opowieści o szeroko pojętym charakterze legendarnym oraz ścisła faktografia wspólnie tworzą mitologiczno-historyczną genezę Portugalii. Według słów Antóniego da Silva Rego, kronikarz „zamyka mitologię w historii", (da Silva Rego, w: de Brito, 1973:XX). Nie powinno nas to dziwić. Jak pisze Jacek Banaszkiewicz:

do skarbca historii początkowej wkłada zbiorowość wszystkie kosztowności, jakie ma. Deponuje tam ważne dla kultury i racji bytu kraju wartości, zwyczaje, ryty. Do „narodowej” rekwizytorni wprowadza wszystkich bohaterów, dzięki którym wspólnota powstała i broniła swojej odrębności (Banaszkiewicz, 1998: 5).

9 Przy czym taka mieszanka wątków nie pojawia się wyjątkowo u tego jedynego autora - podobnie wiążą ze sobą różne elementy przeszłości inni autorzy tego okresu, na przykład António de Sousa de Macedo we wspomnianej już pracy panegirycznej łączącej dzieje Portugalii z chorograficzną pochwałą regionu Flores de España, excelencias de Portugal (1631) (porównaj na przykład Działak-Szubińska, 2015: 1-18). 
I tak drugi tom pracy, który rozpoczyna się od narodzin Chrystusa, zaś kończy się na utworzeniu hrabstwa Portugalii, zawiera głównie wątki historyczne tylko przeplecione elementami fantastycznymi. Z kolei w pierwszym tomie znajdziemy dużo więcej elementów typowo „bajecznych”, związanych z genezą biblijną czy mitologiczną. Innymi słowy, odnosząc się do terminologii zaaplikowanej przez Jacka Banaszkiewicza do polskich dziejów bajecznych, de Brito prezentuje całość opowieści „de origines” - pochyla się nad genezą ludu oraz nad genezą królestwa (por. Banaszkiewicz, 1998).

\section{5.}

\section{Cele Monarchia Lusitana Bernarda de Brito}

Wypada się więc teraz zastanowić, jakie cele przyświecają autorowi dwóch pierwszych części Monarchia Lusitana. Zwróćmy uwagę, że Bernardo de Brito sięga do dziejów bardzo odległych, a wszystkie przedstawiane wątki układają się w spójną narrację o przeszłości Portugalii. Jak wspomniałam, przeszłość ta sięga dużo wcześniej niż moment, w którym w XII wieku pojawia się na mapie królestwo Portugalii. Autor de facto rozszerza dzieje swojego państwa o czasy przed jego faktycznym powstaniem i włącza dzieje bajeczne oraz starożytne do jej historii - „Nação Portuguesa” (de Brito, 1973: 219r), „Terras de Portugal” (de Brito, 1973: 219v) to określenia, których używa chociażby w odniesieniu do Luzytanów. W wizji Bernarda de Brito Tubal czy Wiriatus to zatem nie tyle mityczni protoplaści mieszkańców Półwyspu Iberyjskiego, co właśnie Portugalii - miejsca, w którym osiadają pierwsi ludzie na Półwyspie i powstają najstarsze organizmy państwowe, od których bezpośrednio wywodzi się królestwo Portugalii. Tym samym dziejopis zaświadcza o dawności swej ojczyzny - w jego ujęciu korzenie Portugalii sięgają aż do czasów Tubala, a Portugalia i związana z nią tożsamość istnieje stale od czasów pierwszej kolonizacji pomimo najazdów rzymskich, barbarzyńskich czy muzułmańskich. W takim ujęciu widzimy więc wyraźnie spójność, ciągłość, ale też dawność dziejów Portugalii (porównaj Gloël, 
2017: 36 a także kolejne, Łukaszyk, 2003: 93). Wspominałam już, że ta wizja zarysowuje się nawet na poziomie samego tytułu - wszak wynika z niego, że „Monarchia Luzytańska”, a więc Portugalia, ma swoje korzenie niemalże w „początkach świata”.

Ta ciągłość zostaje oddana nie tylko przez spójną sekwencję narracyjną i traktowanie mieszkańców ziem Portugalii jak Portugalczyków, ale też poprzez paralele do czasów bliższych autorowi. Przykładowo, pisząc o założeniu Lizbony przez Ulissesa, Bernardo de Brito nawiązuje do późniejszej świetności miasta osiągniętej za czasów portugalskiego króla Manuela (de Brito, 1973: 67r). Co ważne, kronikarz podkreśla też szczególne cechy Portugalczyków. W opowieści o Herkulesie zaznacza na przykład, że mieszkańcy Portugalii byli bardziej zaawansowani politycznie od innych ludów Półwyspu Iberyjskiego (de Brito, 1973: 31r-31v). Cysters przygląda się zatem domniemanym korzeniom biblijnym, antycznym oraz chrześcijańskim i dostrzega spójność oraz celowość dziejów Portugalii, a także upatruje powodów do dumy w jej dawności i szczególnych predyspozycjach intelektualnych. Prymat Portugalii, czy też Luzytanii, jest jedną z myśli przewodnich pracy.

Jak zaznacza Krzysztof Pomian, o ile w średniowieczu dzieje bajeczne służyły wpisaniu historii własnej w dzieje powszechne, o tyle w epoce nowożytnej możemy wyraźnie odtworzyć siatkę interesów, których obronie służą narracje „o początkach” (Pomian, 2010: 63, przypis 105). Podobnie José Eduardo Franco zauważa: w epoce nowożytnej dziejopisarstwo wykorzystywało doskonalsze niż wcześniej narzędzia badawcze, przy czym nadal było silnie osadzone w splocie politycznych zależności (Franco, 2000: 190). Doskonałym tego przykładem wydaje się właśnie Monarchia Lusitana, która, paradoksalnie, poprzez rzetelną pracę źródłową ${ }^{10}$ realizuje cele stawiane przed „historią heroiczną" (da Silva Rego, w: de Brito, 1973: XX). I tak widzimy, że w pracy Bernarda de Brito znajomość paleografii, praca na różnorodnym materiale źródłowym, szczegółowe wyliczenia i rzetelne

10 António da Silva Rego pisze w kontekście pracy de Brito wręcz o naukach pomocniczych historii (por. da Silva Rego, w: de Brito, 1973: XX). 
cytaty oraz deklaratywna chęć dotarcia do prawdy łączą się z wizją dziejów jako źródła nauk umoralniających i „teatru życia ludzkiego" (de Brito, 1973: 3r), a także mocno średniowieczną oprawą ideologiczną, chociażby prowidencjalizmem ${ }^{11}$. Można więc zauważyć, że autor łączy w pracy dokonania „szkoły erudycyjnej” (por. Pomian, 2010) z przedmiotowym traktowaniem materiału kronikarskiego i aktowego.

Założenia Monarchia Lusitana mogą wskazywać na jej polityczno-parenetyczną przydatność. Nieprzypadkowo wątek „początków" powraca ze szczególnym natężeniem w kontekście unii iberyjskiej, która w 1581 roku oficjalnie połączyła Portugalię i Hiszpanię pod berłem Habsburgów. Okres ten - pomimo nieobecności królewskiego dworu w Lizbonie i tym samym ograniczenia mecenatu - był niezwykle bogaty literacko, przy czym w literaturze i sztuce portugalskiej tego okresu Lizbona była przedstawiana jako osamotniona i smutna wdowa po królewskim małżonku, co należy wiązać właśnie z ograniczonym zainteresowaniem hiszpańskich monarchów - Filip II (I) i Filip III (II) gościli w Portugalii raz, zaś Filip IV (III) nigdy (Bouza Álvares, 1994: 71-93). Należy tu również zaznaczyć, że o ile początkowo Portugalia korzystała w ramach unii z licznych przywilejów zaprzysiężonych przez Filipa II (I) podczas kortezów w Tomar w 1581 roku, z czasem stały się one niewygodne z perspektywy centralizacyjnych dążeń hiszpańskich monarchów. Nie dziwi w tym kontekście chęć zwrócenia uwagi Filipów na bogactwo gospodarcze, kulturowe, a także historyczne Portugalii i uwypuklenie jej atutów. Te enkomiastyczne próby literackie były tak powszechne, że portugalscy badacze mówią wręcz o oddzielnym nurcie literackim - literaturze autonomistycznej, ukierunkowanej na pochwałę Portugalii, ale też osadzonej w kontekście walki o respektowanie przyobiecanych przez Filipa II (I) swobód (porównaj Cidade, 1950). W ten kontekst można wpisać chociażby wspomnianych już Fernão de Oliveirę i Antóniego de Sousę de Macedo. Nadmieńmy, że

11 Szerzej o tych kwestiach w kontekście europejskim zob. Pomian, 2010: 345 . 
szczególną rolę w tym okresie zyskuje właśnie historiografia (por. na przykład Łukaszyk, 2003: 91 i kolejne; Vásquez Cuesta, 1986: 106). Przy czym należy jednak podkreślić, że uwypuklenie zasług Portugalczyków i podkreślanie zalet Portugalii nie są raczej tożsame z nawoływaniem do buntu przeciw Hiszpanom. Niektórzy autorzy uznawani za „,autonomistycznych”, wśród nich Bernardo de Brito, mieli wręcz silne związki z Habsburgami i wiele im zawdzięczali (por. Gloël, 2017: 31-35).

Stąd też można założyć, że treści apologetyczne zawarte w Monarchia Lusitana miały przypominać Filipom, że Portugalia jest od wieków integralną i, co ważne, kluczową kulturowo i historycznie częścią Półwyspu Iberyjskiego, zaś nierespektowanie jej praw oraz przywilejów naruszy status quo, zerwie praktycznie nieprzerwaną ${ }^{12}$ od czasów Tubala, Wiriatusa i innych, nić (por. Łukaszyk, 2003: 93). W tym kontekście Pilar Vásquez Cuesta mówi wręcz o celowym przekazywaniu skarg (Vásquez Cuesta, 1986: 106). Nieprzypadkowo w prologu do drugiego tomu dzieła Bernardo de Brito podkreśla, że żadne królestwo, które należy do Filipa, nie może się równać z Portugalią (de Brito, 1975: bez numeracji kart). Cysters niejako promuje Portugalię, uwypukla jej atuty w oczach hiszpańskich monarchów, ale nie buntuje się przeciw unii (por. Gloël, 2017: 42). Bernardo de Brito był zresztą w wyjątkowo uprzywilejowanej pozycji jako beneficjent nadań Filipów (por. Gloël, 2017: 33-34).

W tym kontekście nie można wykluczyć, że cystersom przyświecały doraźne i pragmatyczne potrzeby umocnienia swojej pozycji w Portugalii połączonej unią z Hiszpanią. Widzimy to wyraźnie chociażby we wspominanej Chronica de Cister autorstwa Bernarda de Brito, apologii portugalskich cystersów. Wreszcie nie można też zapominać, że adresatami tej i innych podobnych prac są sami Portugalczycy, w szczególności wysoko urodzeni panowie. Cysters wspomina o tym zresztą wprost, kiedy zaznacza, że o pewnych wydarzeniach pisze, by portugalska szlachta „nie zazdrościła innym królestwom Hiszpanii” (de Brito, 1975: 389r).

12 Choć czasami naruszaną, na przykład barbarzyństwem ludów germańskich, por. de Brito, 1975: bez numeracji kart. 
Jak napisała Ewa Łukaszyk:

Cystersi z klasztoru w Alcobaça zapoczątkowują nowego rodzaju twórczość historiograficzną, tworząc monumentalną kronikę królestwa portugalskiego, Monarquia Lusitana. Bez wielkiej przesady można powiedzieć, że stanowi ona ostateczną formę mitologii narodowej, wykrystalizowanej począwszy od wieku XV (Łukaszyk, 2003: 92).

Faktycznie, Bernardo de Brito kładzie podwaliny pod mitologię narodową Portugalczyków poprzez opis „origines”, dotykając tego, co najważniejsze - samych początków Portugalii, której geneza opiera się w dużej mierze na motywach biblijnych (między innymi Portugalczycy jako potomkowie Tubala, wnuka Noego), a także mitologicznych (między innymi wplecenie dziejów własnych w mitologie grecką i rzymską) i historycznych (między innymi połączenie dziejów Portugalii z dziejami między innymi Rzymu). Jak pisze Jacek Banaszkiewicz: „Zamykane w historiograficznych czy ustnych przekazach „origines” były owocem podlegającym zmianom doświadczeń kulturowych wspólnoty i traktowano takie wykłady jako relacje z owej najpierwszej i modelującej przyszłość rzeczywistości” (Banaszkiewicz, 1997: 17). Bernardo de Brito dokonuje zatem swoistego „fałszerstwa”, którego celem jest jednak nie tyle zakłamanie rzeczywistości, co jej zaklinanie, to jest wykazanie, że dzieje Portugalii są przepełnione niezwykłymi wydarzeniami i, przede wszystkim, sięgają swoimi korzeniami dużo dalej niż moment oddzielenia się hrabstwa Portugalii od Kastylii i Leónu oraz rzeczywistego osiągnięcia statusu królestwa. Wypada więc zgodzić się z Ewą Łukaszyk, która napisała o Monarchia Lusitana: „Nie należy jednak przypisywać fałszerzowi niskich pobudek. Lekcją wysnutą z fantastycznej opowieści jest nieprzerwane trwanie narodu luzytańskiego, wywodzonego od biblijnego przodka, zaś dzieje bogate są w wydarzenia o charakterze cudownym" (Łukaszyk, 2003: 93). Rozmijanie się z prawdą i eklektyczna metodologia są bowiem zabiegami celowymi, wpisującymi się w ducha historiografii okresu unii iberyjskiej (Vásquez Cuesta, 1986: 108-109). Z kolei poszukiwanie korzeni 
$\mathrm{w}$ tak dawnych czasach wpisuje się w tendencje europejskie. Argumentacja „z dawności” była niezwykle powszechna, o czym trafnie pisze Henryk Samsonowicz: „Dawny a więc prawdziwy, prawdziwy bo dawny, prawdziwy więc słuszny - tak wyglądała mniej więcej argumentacja uzasadniająca racje jednostek i racje grup (schemat ten działa do dziś)" (Samsonowicz, 1997: 31).

\section{6.}

\section{Wnioski końcowe}

Bernardo de Brito w swojej historii Portugalii, Monarchia Lusitana, stara się wykazać dawność Portugalii i jej szczególne uprzywilejowanie na tle innych nacji iberyjskich. Służy temu odniesienie do korzeni biblijnych, a także antyczno-mitologicznych. W kontekst historyczny autor wplata postaci takie jak Tubal, Ulisses czy Herkules, nie zapomina też o Wiriatusie. Stawia ich na równi z postaciami takimi jak hrabia Henryk, beneficjent nadania Alfonsa VI i ojciec przyszłego pierwszego króla Portugalii. Wszystkie elementy genezy - tak biblijnej, jak i antycznej oraz średniowiecznej, współgrają ze sobą, tworząc spójny obraz państwa o długiej i nieprzerwanej tradycji. Bernardo de Brito sięga zatem korzeni Portugalii - tego, co poprzedza powstanie hrabstwa Portugalii, a następnie fundacji dynastii i państwa, począwszy od hrabiego Henryka, ojca pierwszego króla Portugalii.

Mityczna geneza Portugalii opiera się na wielości motywów opartych na dziedzictwie grecko-rzymskim i judeo-chrześcijańskim zanurzonych w historycznej oprawie i opartych na pewnym kanonie. Bernardo de Brito nie jest zresztą jedynym autorem tego okresu, który odwołuje się do opowieści „de origines” Portugalii i upatruje przyczyn jej wyjątkowości w przeszłości biblijnej, antycznej i średniowiecznej, czerpiąc siłę i dumę z jej dawności. Celem tej i innych prac nie jest zatem przekazanie faktografii - prymat Portugalii, godne korzenie i całościowa pochwała dziejów służą obronie portugalskiej racji stanu. 


\section{Bibliografia}

Banaszkiewicz, J. (1998): Polskie dzieje bajeczne Mistrza Wincentego Kadłubka. Wrocław: Wydawnictwo Leopoldinum.

Banaszkiewicz, J. (1997): Podania o "początku», w: A. Mączak (ed.), Dynastie Europy, Wrocław: Wydawnictwo Ossolineum: $17-45$.

Bouza Álvares, F. (1994): Lisboa Sozinha, Quase Viúva. A Cidade e a Mudança da Corte no Portugal dos Filipes. "Penélope. Fazer e Desfazer a História" 13: 71-93.

Brandão, A. (1632): Terceira Parte da Monarchia Lusitana que contem a Historia de Portugal desdo Conde Dom Henrique, até todo o reinado del Rey Dom Afonso Henriques. Lisboa: Pedro Craesbeck.

Curtius, E.R. (1997): Literatura europejska i łacińskie średniowiecze, tłumaczenie A. Borowski. Kraków: Universitas.

da Silva, B. (1620): Defensam da Monarchia Lusitana. Por Frey Bernardino da Sylva, Bacharel formado em sancta Theologia, Lente della, \& Philosophia, Religioso professo do Real Mosteiro de Alcobaça Congregação de Cister: Primeira Parte. Offerecido ao Duque dom Theodosio, segundo deste nome, Duque de Bragança, Conde de Ourem, de Arrayolos, de Neiva, \& Penafiel, senhor de Monforte, Montalegre, \& villa de Conde, Condestable destes Reynos, \& senhorios de Portugal. Com todas as licenças necessarias. Em Coimbra, Na Officina de Nicolao Carvalho. Anno M. DCXX. Coimbra: Nicolau Carvalho.

de Brito, B. (1602): Primeyra Parte da Chronica de Cister, Onde se Contam Cousas Principais Desta Religiam com Muytas Antiguidades, Assi do Reyno de Portugal Como de Outros Muytos da Christandade. Composta por Frey Bernardo de Brito Religioso, \& Chronista Geral da Propria Ordem, [Com] [L]icença da Sancta Inquisição \& Privilegio Real. Em Lisboa. [Na Officina de] Pedro Crasbeek. Anno de 1602. Lisboa: Pedro Crasbeek.

de Brito, B. (1690a): Monarchia Lusitana composta por Frey Bernardo de Brito. Chronista Geral, e religioso da ordem de S. Bernardo. Professo no Real Mosteiro de Alcobaça. Parte primeira que contèm as historias de Portugal, desde a Criação do Maundo até o Nascimento de nosso senhor Jesu Christo. Dirigida ao 
Muito Alto, e Muito Poderoso Rey, e Senhor Nosso D. Pedro II. Lisboa. Com as Licenças necessarias. Na Impressaõ Creaesbeeckiana. Anno 1690. Lisboa: Impressão Creaesbeeckiana.

de Brito, B. (1690b): Segunda parte da Monarchia Lusitana. Em que se continuaõ as historias de Portugal, desde o Nascimento de nosso Salvador Jesu Christo, até ser dado em dote ao Conde Dom Henrique. Composta pelo doutor frey Bernardo de Brito. Chronista Geral, e Monge da Ordem de S. Bernardo. Dirigida ao Muito Alto, e Muito Poderoso Rey, e Senhor Nosso D. Pedro II. Lisboa. Com as Licenças necessarias. Na Impressaõ Creaesbeeckiana. Anno 1690. Lisboa: Impressão Creaesbeeckiana.

de Brito, B. (1973): Monarquia Lusitana. Parte Primeira, intr. A da Silva Rego, n. A.A. Banha de Andrade and M. dos Santos Alves. Lisboa: Imprensa Nacional-Casa da Moeda.

de Brito, B. (1975): Monarquia Lusitana. Parte Segunda, intr. A da Silva Rego, n. A.A. Banha de Andrade and M. dos Santos Alves. Lisboa: Imprensa Nacional-Casa da Moeda.

Camões, Luís Vaz de (1995): Luzytanie, tłum. I. Kania. Kraków: Wydawnictwo Literackie.

Cidade, H. (1950): A Literatura Autonomista sob os Filipes. Lisboa: Livraria Sá da Costa.

Crónica Geral de Espanha de 1344. Volume I (1951): L.F. Lindley Cintra (ed.). Lisboa: Academia Portuguesa da História.

Długosz, Jan (2009): Jana Długosza roczniki czyli kroniki sławnego Królestwa Polskiego. Księga druga do 1038, J. Dąbrowski (red.). Warszawa: Wydawnictwo Naukowe PWN.

Działak-Szubińska, A. (2015): Kwiaty Hiszpanii, wspaniałości Portugalii czyli jak udowodnić «siłę» Portugalczyków, „Res Rhetorica" 4: 1-18.

Franco, J.E. (2000): O mito de Portugal. A primeira história de Portugal e a sua função política. Lisboa: Roma Editora.

Gloël, M. (2017): Bernardo de Brito: A Misunderstood Portuguese Chronicler. "e-JPH" 15: 30-44.

Os Livros de Linhagens, w: Herculano, A. (ed.) (1860): Portugaliae Monumenta Historica a Saeculo Octavo Post Christum Usque ad Quintumdecimum. Issu Academiae Scientarum Olisiponensis. Edita. Scriptores. Volumen I. Fasciculus II. Olisipone. Tipis 
Academicis MDCCCLX. Lisboa: Academia Portuguesa das Ciências de Lisboa.

Łukaszyk, E. (2003): Terytorium a świat. Wyobrażeniowe konfiguracje przestrzeni w literaturze portugalskiej od schyłku średniowiecza do współczesności. Kraków: Wydawnictwa Uniwersytetu Jagiellońskiego.

Macedo, A. de Sousa de (1631): Flores de España, excelencias de Portugal, en que brevemente se trata lo mejor de sus historias, $y$ de todas las del mundo desde su principio hasta nuestros tiempos, y se descubren muchas cosas nuevas del provecho, y curiosidad. Primera Parte a la Magestad del Rey Catholico de las Españas Don Philippe IIII nuestro Señor. Lisboa: Jorge Rodrigues.

Ocieczek, R. (1990): O różnych aspektach badań literackiej ramy wydawniczej w ksiażkach dawnych, w: R. Ocieczek (ed.), O literackiej ramie wydawniczej w ksiażkach dawnych. Katowice: Uniwersytet Śląski: 7-19.

Pawlak, W. (2012): De eruditione comparanda in humanioribus. Studia zdziejów erudycji humanistycznej w XVII wieku. Lublin: Wydawnictwa KUL.

Pomian, K. (2010): Przeszłość jako przedmiot badań. Warszawa: Wydawnictwa Uniwersytetu Warszawskiego.

Rodrigues, Graça de Almeida (1980): Breve história da censura literária em Portugal. Lisboa: Instituto de Cultura Portuguesa.

Samsonowicz, H. (1997): Mity «Początku», w: O „historii prawdziwej”. Mity, legendy i podania jako źródło historyczne. Gdańsk: Novus Orbis: $27-40$.

Saraiva, J.H. (2000): Krótka historia Portugalii, tłum. E. Łukaszyk. Kraków: Wydawnictwo Universitas.

Saraiva, J.A. and Lopes, Ó. (1996): História da Literatura Portuguesa. Porto: Porto Editora.

Vásquez Cuesta, P. (1986): A Língua e a Cultura Portuguesas no Tempo Dos Filipes. Lisboa - Publicações Europa-América. 